DiRECTEUR DE LA PUBLICATION: Bruno David,

Président du Muséum national d'Histoire naturelle

RÉdACTEUR EN CHEF / EDITOR-IN-CHIEF: Didier Merle

ASSISTANTS DE RÉDACTION / AsSISTANT EDITORS: Emmanuel Côtez (geodiv@mnhn.fr); Anne Mabille

Mise EN PAGE / PAGE LAYOUT: Emmanuel Côtez

COMITÉ SCIENTIFIQUE / SCIENTIFIC BOARD:

Christine Argot (MNHN, Paris)

Beatrix Azanza (Museo Nacional de Ciencias Naturales, Madrid)

Raymond L. Bernor (Howard University, Washington DC)

Alain Blieck (USTL, Villeneuve d'Ascq)

Henning Blom (Uppsala University)

Jean Broutin (UPMC, Paris)

Gaël Clément (MNHN, Paris)

Ted Daeschler (Academy of Natural Sciences, Philadelphie)

Bruno David (MNHN, Paris)

Gregory D. Edgecombe (The Natural History Museum, Londres)

Ursula Göhlich (Natural History Museum Vienna)

Jin Meng (American Museum of Natural History, New York)

Brigitte Meyer-Berthaud (CIRAD, Montpellier)

Zhu Min (Chinese Academy of Sciences, Pékin)

Isabelle Rouget (UPMC, Paris)

Sevket Sen (MNHN, Paris)

Stanislav Štamberg (Museum of Eastern Bohemia, Hradec Králové)

Paul Taylor (The Natural History Museum, Londres)

COUVERTURE / COVER:

Réalisée à partir des Figures de l'article/created from the Figures of this article.

Geodiversitas est indexé dans / Geodiversitas is indexed in:

- Science Citation Index Expanded (SciSearch ${ }^{\circledR}$ )

- ISI Alerting Services ${ }^{\circledR}$

- Current Contents ${ }^{\circledR}$ / Physical, Chemical, and Earth Sciences ${ }^{\circledR}$

- Scopus ${ }^{\circledR}$

Geodiversitas est distribué en version électronique par / Geodiversitas is distributed electronically by:

- BioOne ${ }^{\circledR}$ (http://www.bioone.org)

Les articles ainsi que les nouveautés nomenclaturales publiés dans Geodiversitas sont référencés par / Articles and nomenclatural novelties published in Geodiversitas are referenced by:

- ZooBank ${ }^{\circledR}$ (http://zoobank.org)

Geodiversitas est une revue en flux continu publiée par les Publications scientifiques du Muséum, Paris Geodiversitas is a fast track journal published by the Museum Science Press, Paris

Les Publications scientifiques du Muséum publient aussi / The Museum Science Press also publish: Adansonia, Zoosystema, Anthropozoologica, European Journal of Taxonomy, Naturae.

Diffusion - Publications scientifiques Muséum national d'Histoire naturelle

CP $41-57$ rue Cuvier F-75231 Paris cedex 05 (France)

Tél. : 33 (0)1 40794805 / Fax: 33 (0)1 40793840

diff.pub@mnhn.fr / http://sciencepress.mnhn.fr

(C) Publications scientifiques du Muséum national d'Histoire naturelle, Paris, 2018

ISSN (imprimé / print): 1280-9659/ ISSN (électronique / electronic): 1638-9395 


\title{
Prayers for fossil mantis unfulfilled: Prochaeradodis enigmaticus Piton, 1940 is a cockroach (Blattodea)
}

\author{
Yingying CUI \\ Guangzhou Key Laboratory of Insect Development Regulation and Application Research, \\ Institute of Insect Science and Technology \& School of Life Sciences, \\ South China Normal University, 510631 Guangzhou (China) \\ cuiying19860105@gmail.com (corresponding author) \\ Dominic A. EVANGELISTA \\ ISYEB (MNHN, CNRS, UPMC, EPHE, Sorbonne Université), \\ Institut de Systématique, Évolution, Biodiversité, UMR 7205, \\ Muséum national d'Histoire naturelle, \\ case postale 50, 57 rue Cuvier, F-75231 Paris cedex 05 (France) \\ dominicev@gmail.com \\ Olivier BÉTHOUX \\ CR2P (CNRS, MNHN, UPMC, Sorbonne Université), \\ Centre de Recherches sur la Paléobiodiversité et les Paléoenvironnements, \\ Muséum national d'Histoire naturelle, \\ case postale 38, 57 rue Cuvier, F-75231 Paris cedex 05 (France) \\ obethoux@mnhn.fr
}

Submitted on 10 January 2018 | accepted on 3 April 2018 | published on 2 August 2018

KEY WORDS

Polyneoptera,

Blattaria,

Blattoptera,

Blattida,

morphology, palaeoentomology.
urn:Isid:zoobank.org:pub:427386D1-686A-4E45-903A-8AB9442610CC

Cui Y., Evangelista D. A. \& Béthoux O. 2018. - Prayers for fossil mantis unfulfilled Prochaeradodis enigmaticus Piton, 1940 is a cockroach (Blattodea). Geodiversitas 40 (15): 355-362. https://doi.org/10.5252/geodiversitas2018v40a15. http://geodiversitas.com/40/15

\section{ABSTRACT}

The fossil species Prochaeradodis enigmaticus Piton, 1940, from Menat (France, Paleocene) has been regarded as a crown-Mantodea (praying mantis) and was subsequently used as one of the very few temporal calibration points relevant for the order. Ambiguities in previous descriptions prompted us to re-examine the type material. Based on our new observations and a broad comparative analysis across Dictyoptera, we recognized three independent morphological character states supporting an unequivocal placement of the fossil within Blattodea (cockroaches and termites). These states are: 1) in forewing, the AA area has intercalary veins; 2) in forewing, ScP is short and oblique; and 3) in hind wing, CuA has many posterior branches not reaching the posterior wing margin but the cubital furrow. This new placement discounts the use of this fossil as a Mantodea tree calibration point. 
MOTS CLÉS

Polyneoptera

Blattaria,

Blattoptera,

Blattida,

datation,

morphologie,

paléoentomologie.

\section{RÉSUMÉ}

Prières pour une mante fossile non exaucées: Prochaeradodis enigmaticus Piton, 1940 est une blatte (Blattodea). L'espèce fossile Prochaeradodis enigmaticus Piton, 1940, de Menat (France, Paléocène), a été considérée comme un Mantodea couronne (mante religieuse) et a été, par la suite, utilisé comme l'un des rares points de calibration temporelle pertinents pour l'ordre. Des ambiguïtés dans les précédentes descriptions nous ont amenés à revoir le matériel type. Sur la base de nouvelles observations et d'une analyse comparative couvrant les Dictyoptera, nous avons identifié trois états de caractères soutenant, sans le moindre doute, un placement du fossile au sein des Blattodea (blattes - incluant les termites). Ces états sont: 1) chez les ailes antérieures, aire AA avec des nervures intercalaires; 2) chez les ailes antérieures, $\mathrm{ScP}$ courte et oblique; et 3) chez les ailes postérieures, $\mathrm{CuA}$ avec de nombreuses branches postérieures n'atteignant pas le bord postérieur mais le sillon cubital. Ce nouveau placement compromet l'usage de ce fossile comme point de calibration de l'arbre des Mantodea.

\section{INTRODUCTION}

The biologically rich fossil deposits in Menat, France contain a wide array of phyla (Piton 1940; Kedves 1982; Wappler et al. 2009; Stroiński \& Szwedo 2012). Dating from the period immediately succeeding the K-T impact, many of its insect fossils can be attributed to extant families (Nel \& Roy 1996; Nel 2008; Stroiński \& Szwedo 2012; Evangelista et al. 2017; among others).

The Dictyoptera (a taxon encompassing cockroaches, termites and praying mantises) first found in Menat were described by Piton $(1939 ; 1940)$. Subsequent publications have added to this fauna (e.g. Nel \& Roy 1996) or revised the original taxonomic work (Nel \& Roy 1996; Evangelista et al. 2017). One species from Menat, Prochaeradodis enigmaticus Piton, 1940, gained a particular importance in dating analyses. After it was redescribed by Nel \& Roy (1996) it was subsequently considered the oldest fossil representative of the super-family Mantoidea sensu Grimaldi (2003).

Upon examination of the original fossil material, we found compelling evidence for a further revision of P. enigmaticus. Based on supporting morphological evidence, we place this fossil in Blattodea, and as a putative member of the family Blaberidae.

\section{MATERIAL AND METHODS}

\section{Wing morphology terminology and venation homologies}

General wing morphology terminology follows Brannoch et al. (2017). We follow the serial insect wing venation ground-plan of Lameere $(1922,1923)$. The corresponding wing venation nomenclature is repeated for convenience, with indication of colour coding:

AA anterior analis (pink, in forewing only);

$\mathrm{Cu} \quad$ cubitus (green, in hind wing only);

$\mathrm{CuA}$ anterior cubitus;

$\mathrm{CuP} \quad$ posterior cubitus;

M media;

$\mathrm{R} \quad$ radius (blue, in hind wing only);

RA anterior radius;

$\mathrm{RP} \quad$ posterior radius

ScP posterior subcosta (orange, in forewing only).
Besides minor aspects of terminology ('Rs' vs 'RP'), there is broad consensus on the wing venation homologies for cockroaches (except for veins located in the vicinity of the $\mathrm{CuP}$ and of the plica prima anterior). As for mantises, issues remain regarding the homologies of the radial and median system in forewing (OB pers. obs.). In this contribution we do not differentiate among the systems and both are collectively labelled 'R\&M'. These aspects bear no implications on our conclusions.

\section{MATERIAL PREPARATION AND DATA}

The holotype of Prochaeradodis enigmaticus is housed in the Palaeontology Unit of the Muséum national d'Histoire naturelle, Paris (specimen no. MNHN.F.R07003).

Draft drawings of the fossil (Fig. 1) were produced with the aid of a microscope equipped with a camera lucida (Zeiss SteREO Discovery V8 stereomicroscope equipped with a pair of W-PL 10×/23 eye pieces, a Plan Apo S 1.0× FWD objective; all Zeiss, Jena, Germany). Drawings were finalized using Adobe Illustrator CS6 (Adobe Systems, San Jose, CA, USA) using both draft drawings and photographs.

Photographs were taken using a digital camera Canon EOS 5D Mark III, coupled to a Canon $50 \mathrm{~mm}$ macro lens, or to a Canon MP-E $65 \mathrm{~mm}$ macro lens (all Canon, Tokyo, Japan), both equipped with polarizing filters. The resulting photographs were optimized using Adobe Photoshop CS6 (Adobe Systems, San Jose, CA, USA).

Wings of extant specimens were cut off and mounted in white Euparal medium (Asco Laboratories, Manchester, UK). Slides were then examined and illustrated using the same methods as for the fossil material. The acronym 'IWC OB' refers to the 'Insect Wing Collection O. Béthoux'.

Body length was roughly estimated from the anterior most point of the specimen to the estimated posterior end, assuming the wings either: extend past the end of the body, end at the posterior margin of the body, or the body extends past the wings.

\section{COMPARATIVE ANALYSIS}

The specimen's wing characters were assessed and compared to crown-Dictyoptera based on literature. This was primarily done using data from Rehn (1951) formalized in Evangelista 
A
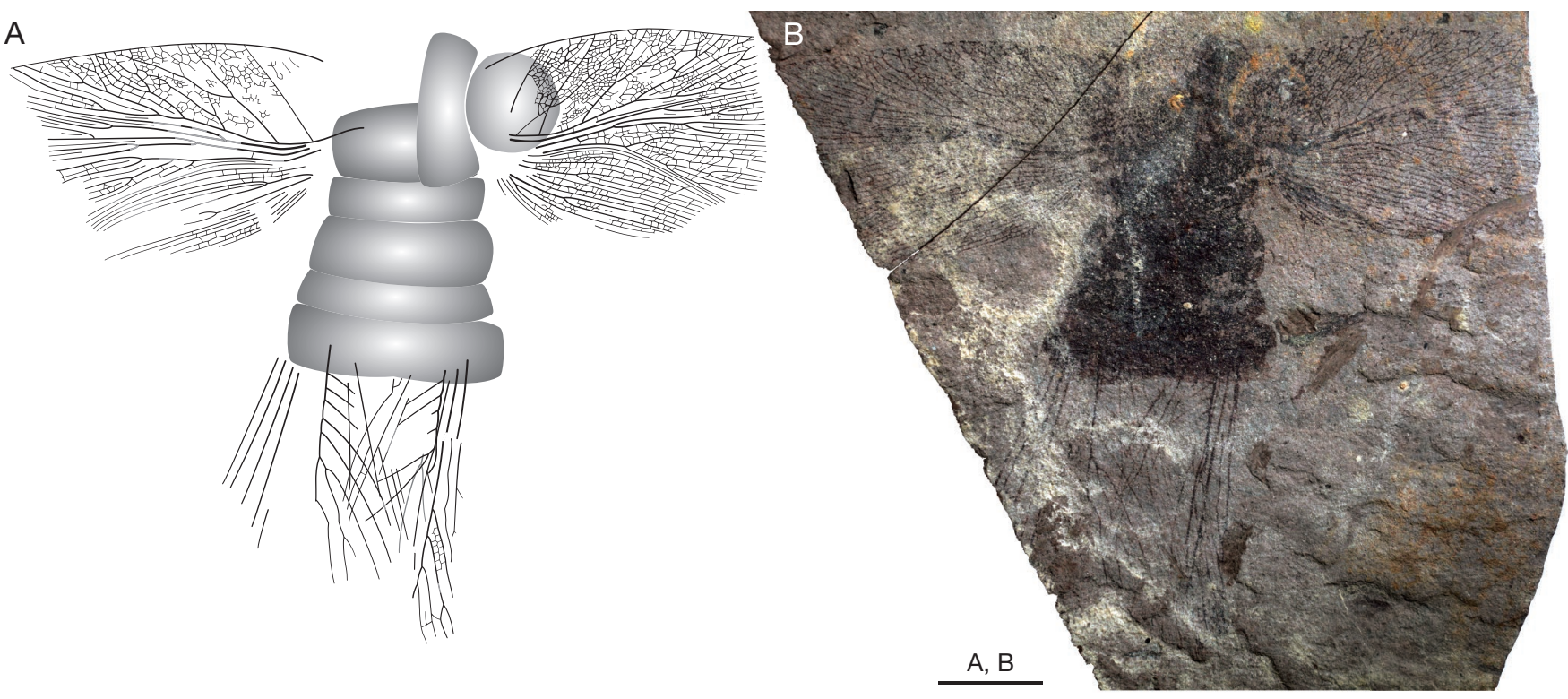

C

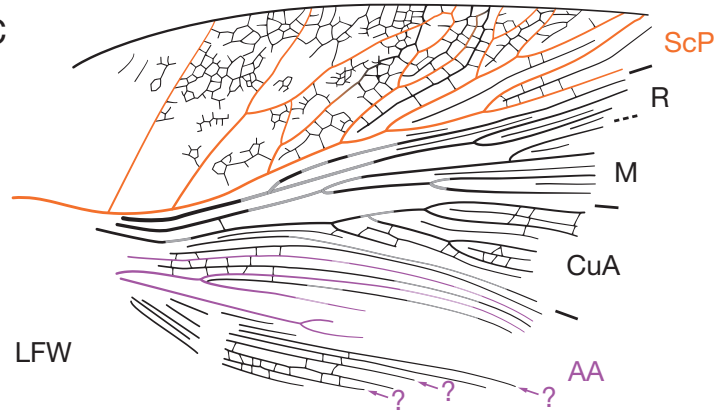

E

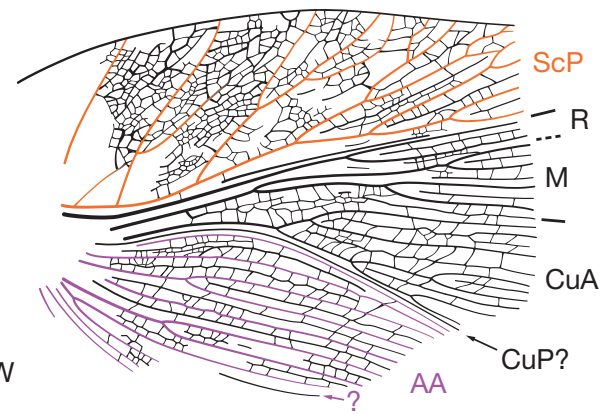

G

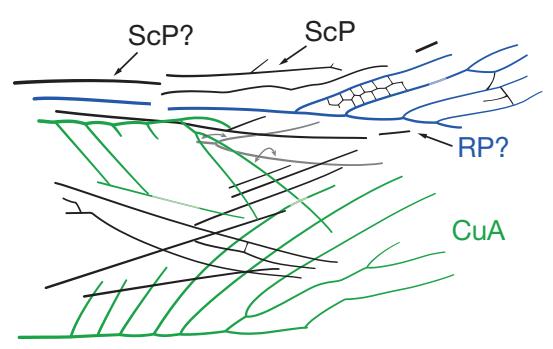

LHW

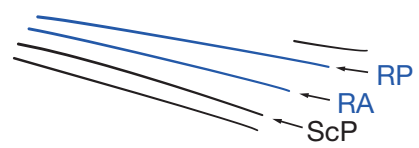

D

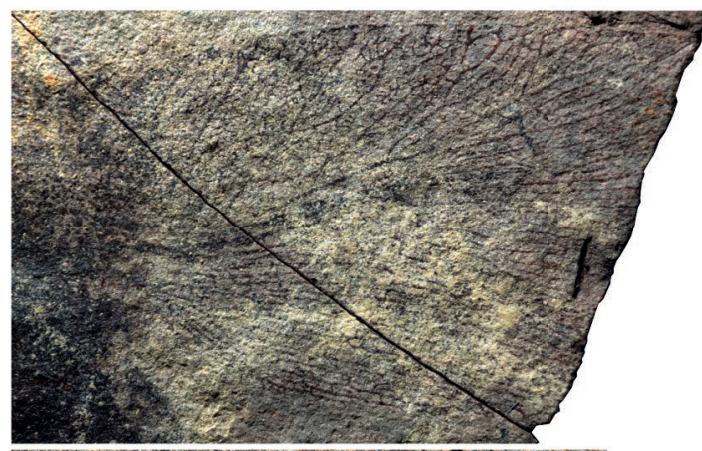

F

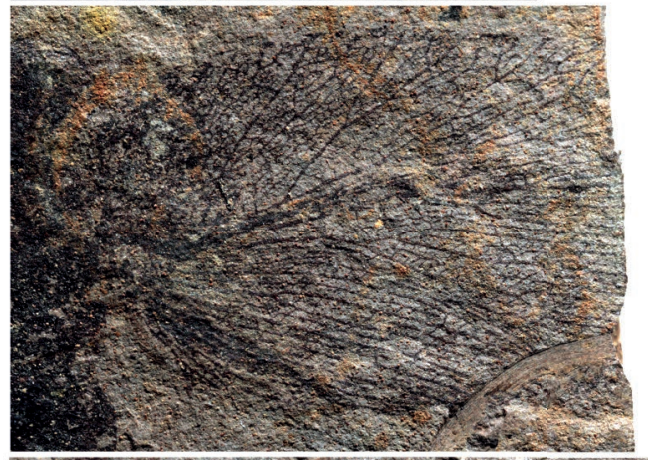

$\mathrm{H}$

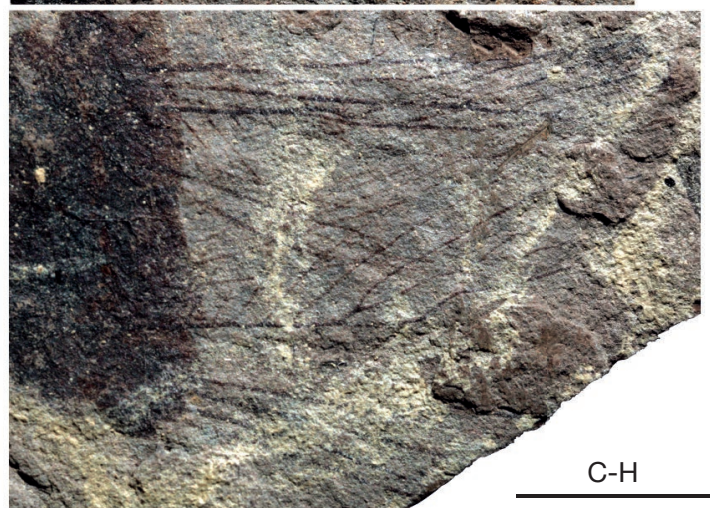

FIG. 1. - Prochaeradodis enigmaticus Piton, 1940, specimen MNHN.F.R07003, positive imprint: A, B, drawing and photograph (dry-ethanol composite) of general habitus; C, D, drawing and photograph (dry-ethanol composite) of left forewing; $\mathbf{E}$, $\mathbf{F}$, drawing and photograph (dry-ethanol composite) of right forewing: G, H, drawing and photograph (dry-ethanol composite) of hind wings. Scale bars: $5 \mathrm{~mm}$. 
et al. (2017), and figures in Rehn (1951) and Brannoch et al. (2017). Illustrations and photos from other publications were used as well (e.g. Anisyutkin 2014, 2015; Hopkins 2014). We also provide a new drawing of a Blaberidae (Fig. 2A, B). Note that, in the corresponding species, a branch of $\mathrm{R}$ diverges posteriorly from $\mathrm{ScP}$ (see Fig. 2A; this trait occurs in many Blattodea; DAE pers. obs.). Polarization of characters was based on fossil families regarded as stem-Blattodea, namely Umenocoleidae, Caloblattinidae, Mesoblattinidae, and Blattulidae (see Martinez-Delclos 1993; Vršanský 2007; Barna 2014; Lee 2016; Vršanský \& Wang 2017) and on Palaeozoic stem-Dictyoptera for which both fore- and hind wing are known with sufficient details (see Béthoux et al. 2011; Guo et al. 2013). Note that, as for the character states considered below, the known stem-Mantodea (see Sharov 1962; Grimaldi 2003; among others) do not differ substantially from the crown-Mantodea documented herein (unless mentioned).

\section{SYSTEMATIC PALAEONTOLOGY}

Super-order DICTYOPTERA Latreille, 1829

Order BLATTODEA Brunner von Wattenwyl, 1882 Family indet.

Genus Prochaeradodis Piton, 1940

Type sPeCIEs. - Prochaeradodis enigmaticus Piton, 1940 monotypic genus.

\section{Prochaeradodis enigmaticus Piton, 1940} (Fig. 1)

TYPE MATERIAL. - Holotype: MNHN.F.R07003, a single imprint of a moderately well-preserved individual, composed of: two forewings with, approximately, the distal half missing; a pair of hind wings with their middle parts partly overlapping, with basal-most part hidden and apex missing; some segments of thorax, head (outline?) and abdomen partly visible.

TyPE LOCALITY. - The material was unearthed at the Menat locality (Puy-de-Dôme, France; Piton 1940), regarded as of Paleocene age (Kedves \& Russell 1982).

\section{REDESCRIPTION}

Body (Fig. 1A, B)

Estimated body length $27-35 \mathrm{~mm}$.

\section{Forewings (Fig. 1C-F)}

Preserved length about 16.2/13.7 mm (left/right forewing, respectively); width (broadest part in the preserved wing) $10.1 / 10.2 \mathrm{~mm}$; area between anterior wing margin and ScP broad, filled with densely reticulated cross-veins; most basal part of that area extremely broad, nearly half of wing width; ScP anteriorly pectinate with secondary forks, with some branches vanishing in the cross-vein network; $\mathrm{R}$ with fewer branches than $\mathrm{M}$ in the preserved part; first fork of $\mathrm{CuA}$ opposite or slightly distal to the first fork of $\mathrm{M}$, with 5-6 branches; CuP (as inferred from actual remains of it or surrounding veins) regularly bent, simple; first AA vein simple, with several additional AA veins, simple or forked; intercalary veins welldeveloped, visible between most main veins.

\section{Hind wings (Fig. 1G, H)}

Preserved length 11.2/13.8 mm (left/right hind wing, respectively); $\mathrm{CuA}$ with numerous posterior pectinate branches, some being branched (9/6 branches preserved in left/right hind wing, respectively); most basal branches of $\mathrm{CuA}$ short and reach $\mathrm{CuP}$ or vanish shortly before reaching it. Right hind wing: wing partly damaged (as evidenced by the discontinuous course of $\mathrm{ScP}, \mathrm{RA}, \mathrm{RP}$ and $\mathrm{CuA}$ ); ScP with (possibly) anterior veinlets; occurrence of an intercaraly vein between ScP and RA; RA anteriorly pectinate with at least five branches; intercalary vein visible between the first two branches of RA; visible branches of $\mathrm{CuA}$ all reaching $\mathrm{CuP}$ (or the cubital furrow, not distinguishable).

\section{REMARKS}

The exact position of $\mathrm{CuP}$ in the forewing is not evident. In extant cockroaches (e.g. Fig. 2A) it seems to be bordered by two vein-like structures of unclear identity. Nonetheless, they are parallel to $\mathrm{CuP}$, hence the course of this vein can be positively assessed based on these. In the right hind wing of the fossil specimen we interpreted an isolated, forked vein (dark grey on Fig. 1G) as a portion of CuA. Given the evidence that this wing is partly damaged, this is the most likely interpretation. Moreover, the resulted reconstruction is consistent with the pattern observed in the other hind wing. Several veins belonging to hind wings could not be positively identified; some probably belong to an expanded plicatum.

\section{DISCUSSION}

Although the fossil is very incomplete there are sufficient character states useful for a critical re-evaluation of its placement. Among Polyneoptera, we agree with Piton (1940) and Nel \& Roy (1996) that P. enigmaticus belongs to Dictyoptera, owing to the posteriorly bent forewing CuP. Note that although it has sometimes been considered diagnostic of Blattodea (herein understood as including "Isoptera") only, this character state is herein regarded as indicative of affinities with the whole Dictyoptera. Indeed, stem-Mantodea (see Gratshev \& Zherikhin 1993; Grimaldi 2003), and, to some extent, Metallyticus spp. (Fig. 2E), display a bent CuP. Within Dictyoptera, we disagree with Piton (1940) and Nel \& Roy (1996) and place this fossil in Blattodea, as opposed to Mantodea. This proposal rests on several character states, as follows.

In forewings of P. enigmaticus (Fig. 1C-F) and of Blattodea (Fig. 2A) the area posterior to $\mathrm{CuP}$ bears abundant AA branches. Furthermore, the AA veins initially diverge basally and then converge apically. In contrast, the anal vein region of Mantodea (Fig. 2C, E, G, I): 1) have fewer branches; and 2) do not display the divergence-convergence pattern (but maybe as a consequence of the straightening of $\mathrm{CuP}$ in some). Stem-Dictyoptera have the same state as in Blattodea. Hence, these states designate P. enigmaticus as either a Blattodea or a stem-Mantodea. 


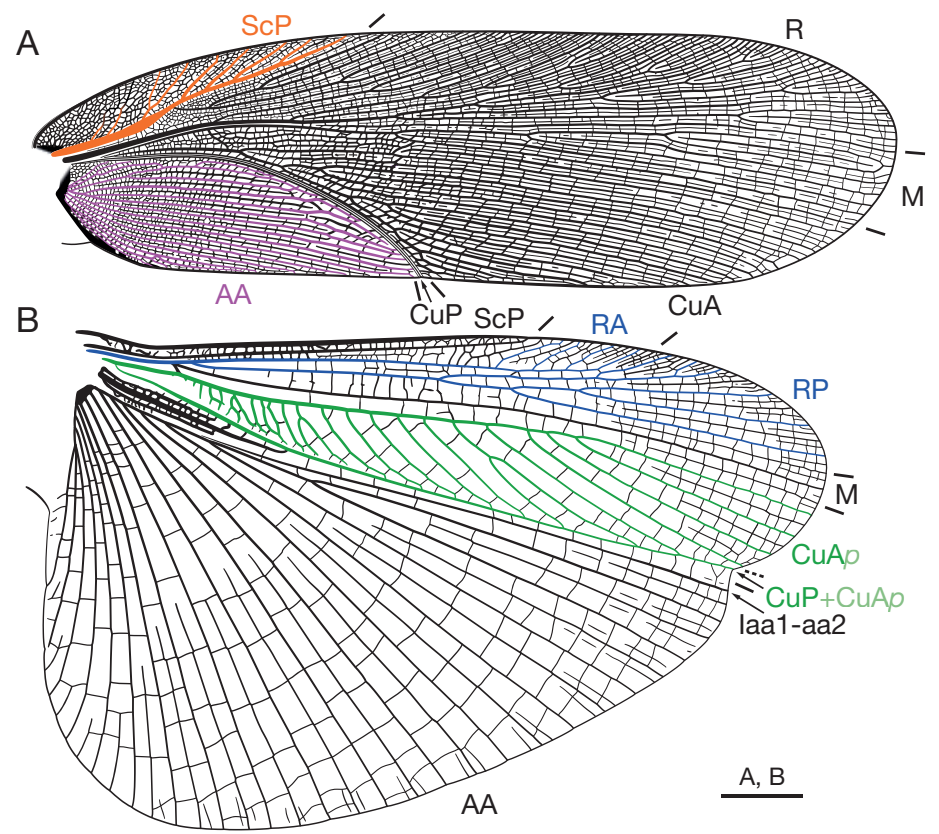

SCP

C

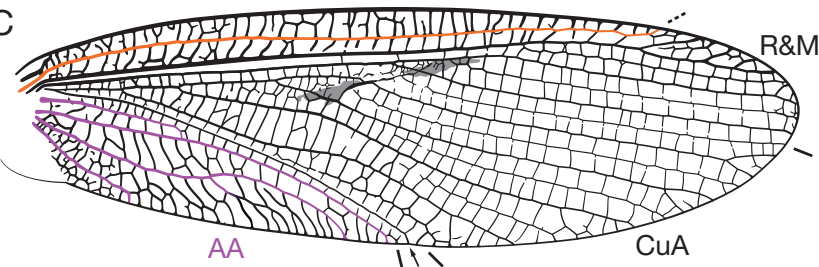

D

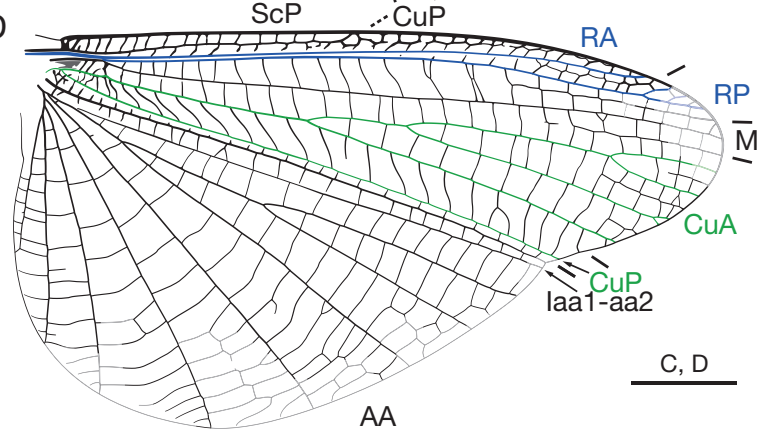

AA

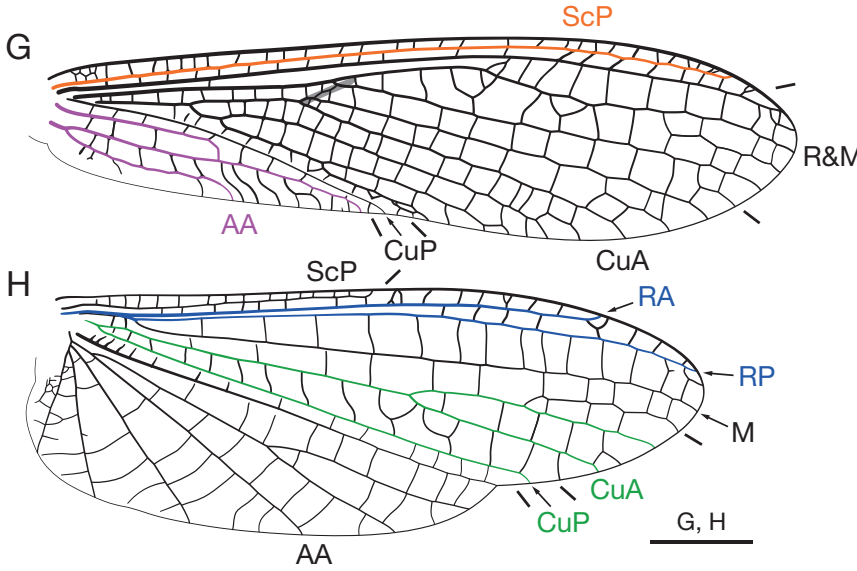

E

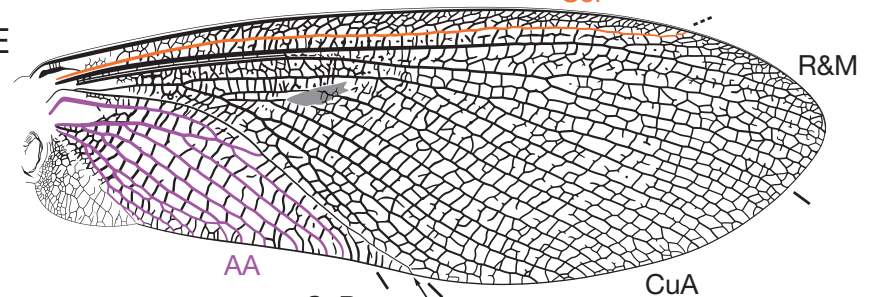

F

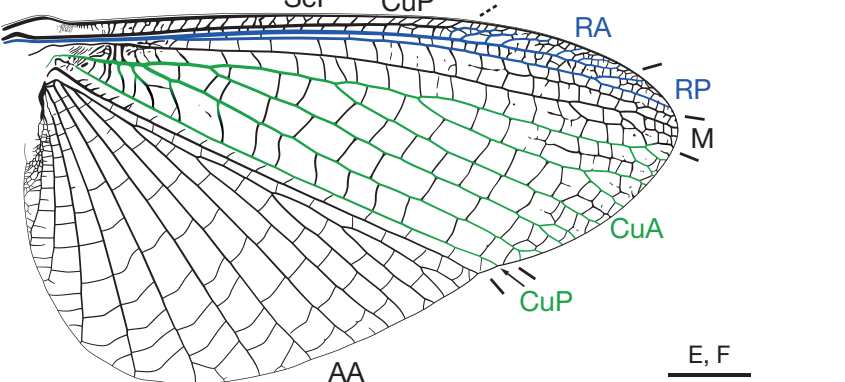

ScP

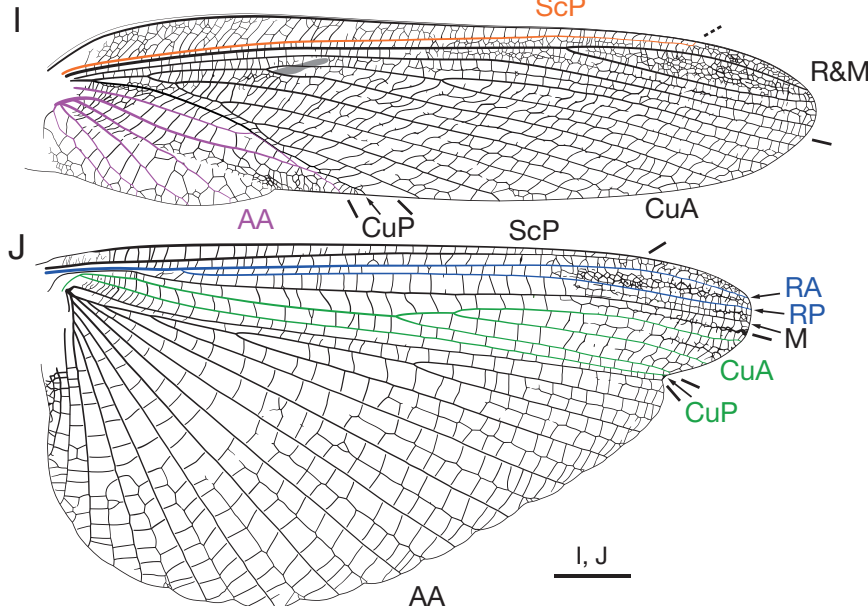

FIG. 2. - Wing venation patterns of selected extant Blattodea and Mantodea: A, B, Molytria sp. (Blattodea; specimen IWC OB 1219), left fore- (A) and hind wing (B); C-J, representatives of Mantodea (modified from Brannoch et al. 2017); C, D, Chaeteessa sp., fore- (C) and hind wing (D); E, F, Metallyticus splendidus Westwood, 1835, fore- (E) and hind wing (F); G, H, Mantoida maya Saussure \& Zehntner, 1894, fore- (G) and hind wing (H); I, J, Mantis religiosa (Linnaeus, 1758), fore- (I) and hind wing (J). Scale bars: A-F, 2 mm; I, J, 3 mm. 
In forewings of $P$. enigmaticus and Blattodea the AA area has intercalary veins (Figs $1 \mathrm{C}-\mathrm{F} ; 2 \mathrm{~A}$ ). This state is absent in all described Mantodea (Fig. 2C, E, G, I). Being absent in stem-Dictyoptera we consider its presence derived within the context of Dictyoptera; hence this state indicates that P. enigmaticus is a Blattodea. Note that the feature is distributed widely within Blattodea (DAE and OB, pers. obs.) but poor documentation of intercalaries in literature disallows further characterization.

Nel \& Roy (1996) referred to the very wide 'costal area' (herein 'area between anterior wing margin -awm- and ScP') as indicative of affinities of P. enigmaticus with Choeradodinae (within Mantodea). However, a wide awm-ScP area is far from unique to a subset of Mantodea: it is indeed common among leaf-mimicking insects. Moreover, this area is wide only in its basal half in P. enigmaticus (Fig. 1C, E) as in Blattodea (Fig. 2A). Although the apical-most section of ScP is not preserved in the fossil, it is highly probable that this vein reached the awm very basally. In contrast, $\mathrm{ScP}$ is very long and parallel to the longitudinal axis of the forewing of Mantodea (Fig. 2C, E, G, I). Stem-Dictyoptera display an intermediate condition, suggesting the short and oblique ScP of Blattodea, and the long and straight ScP of Mantodea are both apomorphic conditions. Hence P. enigmaticus is likely a Blattodea.

In the hind wings of $P$. enigmaticus RA: 1 ) has numerous branches; and 2) its first fork is located basally (Fig. 1G). Nearly all Blattodea have a similar, multiply branched, hindwing RA whose branches originate before the termination of ScP. In the vast majority of Mantodea, RA is simple in the hind wing (Fig. 2H, J). Metallyticus spp. (Fig. 2F) are the only notable exceptions: RA has several anterior branches, but they occur very distally. Additionally, note that some Mantodea, in particular leaf-mimics, can display anterior, weak veinlets diverging from RA, which can hardly be considered genuine branches. Stem-Dictyoptera display the same state as P. enigmaticus and Blattodea, hence the fossil is either a Blattodea or a stem-Mantodea.

In the hind wings of P. enigmaticus $\mathrm{CuA}$ has many posterior branches not reaching the posterior wing margin (pwm) but the cubital furrow (cf) (Fig. 1G). The number of such basal branches varies among Blattodea. Morphologies comparable to that observed in P. enigmaticus (namely, very numerous basal branches) occur in some Blattellinae (family Ectobiidae - probably a paraphyletic assemblage; see, among others, Klass \& Meier 2006, Djernæs et al. 2012, Legendre et al 2015) and Blaberidae (see, e.g., Fig. 2B). In the vast majority of Mantodea, CuA branches all reach the pwm (Fig. 2D, $\mathrm{H}, \mathrm{J}$ ). The only putative exceptions are Metallyticus spp., in which a few structures, located between the main stem of $\mathrm{CuA}$ and cf, could be interpreted as $\mathrm{CuA}$ veinlets (colored as a green-to-black gradient in Fig. 2F). Stem-Dictyoptera display the same state as Mantodea, hence P. enigmaticus is a Blattodea, and likely a relative of Blattellinae or Blaberidae.

Due to the relatively poor preservation, the shape of the pronotum is not evident. However, if it is as described by Nel \& Roy (1996; i.e., with broad side lobes) this is consistent with a placement of P. enigmaticus in Blattodea or as
stem-Mantodea, given that stem-Dictyoptera and nearly all Blattodea possess this state. Note that it must then be assumed that crown-Mantodea secondarily lost the state -except for leaf-mimic ones, which probably re-gained it.

In summary, there is compelling evidence that $P$. enigmaticus is not a Mantodea but a Blattodea, contra Nel \& Roy (1996). To some extent, the position of the species within the latter group can be further investigated. In the forewing of P. enigmaticus $\mathrm{ScP}$ has no apparent posterior branch (herein regarded as the basal-most branch of $\mathrm{R}$ translocated onto ScP; see Material \& Methods and Fig. 2A). Such branch is present in all Blattodea except Blattidae and Blaberidae. The absence of translocation is likely the plesiomorphic state, as it occurs in stem-Dictyoptera. This state indicates that $P$. enigmaticus is likely a crown-Blattidae or crown-Blaberidae, or a stem relative of any other family. As mentioned above, $\mathrm{CuA}$ has many branches reaching of in P. enigmaticus. This state is unique to Blattellinae and Blaberidae. All the characters displayed by this taxon are congruent with a placement in Blaberidae. However, lack of data prevent a formal placement of this taxon as a crown- or stem-representative of this clade (or its sister group).

The wide awm-ScP area and the dense cross-vein reticulation may be reminiscent of leaf mimicry. In following Piton (1940), Nel \& Roy (1996) compared P. enigmaticus with Choeradodis and other genera of leaf-mimicking Mantodea. Among cockroaches, this kind of mimicry mostly occurs in Blaberidae, primarily in Epilamprinae, many of whom have the appearance of dead leaves (DAE, pers. obs.; Anisyutkin 2014, 2015). Nel \& Roy (1996) concluded that these characters are not useful for systematic placement among Mantodea because they may be convergently derived, and we hold the same is true within the context of Blattodea.

The new placement we propose has implications for dating analyses. Grimaldi (2003) cited P. enigmaticus as the oldest fossil member of the Mantodea super-family Mantoidea. It has been subsequently used as a fossil for time calibration of the Mantodea tree in multiple phylogenetic analyses (e.g. Legendre et al. 2015; Wang et al. 2017). The new placement obviously means that it is an inappropriate calibration point for Mantodea. Legendre et al. (2015) also listed Arvenineura insignis Piton, 1940, from the same locality as P. enigmaticus, as stem-Chaeteessidae. The characters listed by these authors are: 1) the shape of the stigma (see footnote to table 1); and 2) the posterior branch of $\mathrm{CuA}$ being simple. As for (1), although the particular state displayed by $A$. insignis was not specified by Legendre et al. (2015), the species shares with Chaeteessidae a comparatively long stigma. This state is a putative plesiomorphy, as it occurs in Cretophotina tristriata Gratshev \& Zerikhin, 1993 (see Grimaldi 2003: fig. 5b, c), regarded as a stem-Mantodea (Grimaldi 2003). As for (2), the state is also a putative plesiomorphy, as it also occurs in C. tristriata but also in Santanmantis axelrodi, both regarded as a stem-Mantodea (Grimaldi 2003). Moreover, it is not present in the holotype of $A$. insignis Pinto, 1940 (Nel \& Roy 1996: fig. 1). In summary, the placement of $A$. insignis as crown-Mantodea 
is not evident. Given the above, to our knowledge, there are no formally described and well-assigned fossil crownMantodea (but see Ehrmann 1999; Zherikhin 2002: fig. 384, and Ross in press)suitable for date calibration.

As a putative Blaberidae from the Menat deposit, P. enigmaticus holds equal ranking with "Gyna" obesa Piton, 1940 as the oldest member of this family (Evangelista et al. 2017). The poor preservation of both fossils unfortunately precludes us from establishing a formal higher-ranking classification to nest these taxa, which may not be closely related.

\section{CONCLUSIONS}

The fossil insect species $P$. enigmaticus, known from a single imprint fossil from Menat, is a representative of Blattodea (possibly a Blaberidae) and not a Mantodea. There are three independent morphological characters supporting this placement unambiguously. The new placement makes it an invalid fossil for calibration of the Mantodea tree, as it has been used in the past. If a Blaberidae, it ranks as the oldest known representative alongside "Gyna” obesa Piton, 1940.

\section{Acknowledgements}

We thank A. Ross (National Museums Scotland, Edinburgh, Scotland) and an anonymous reviewer for useful comments. We are grateful to David Rentz (Cairns, Australia) for providing and identifying extant cockroach material used in this publication. This study was supported by the National Science Foundation of China (Grant no. 31620103917).

\section{REFERENCES}

AnisyutKin L. N. 2014. - On cockroaches of the subfamily Epilamprinae (Dictyoptera: Blaberidae) from South India and Sri Lanka, with descriptions of new taxa. Zootaxa 3847: $301-$ 332. https://doi.org/10.11646/zootaxa.3847.3.1

ANISYUTKIN L. N. 2015. - New and little known Epilamprinae (Dictyoptera: Blaberidae) from the collections of the Muséum d'histoire naturelle de Genève and the Zoological Institute of Saint Petersburg. Part 1. Revue Suisse de Zoologie 122: 283-296. https://doi.org/10.5281/zenodo.30000

BARNA P. 2014. - Low diversity cockroach assemblage from Chernovskie Kopi in Russia confirms wing deformities in insects at the Jurassic/Cretaceous boundary. Biologia 69: 651-675. https:// doi.org/10.2478/s11756-014-0349-9

Béthoux O., Schneider J. W. \& Klass K.-D. 2011. - Redescription of the holotype of Phyloblatta gaudryi (Agnus, 1903) (Pennsylvanian; Commentry, France), an exceptionally well preserved stem-dictyopteran. Geodiversitas 33: 625-635. https:// doi.org/10.5252/g2011n4a4

Brannoch S. K., Wieland F., Rivera J., Klass K.-D., BéthouX O. \& SVENSON G. J. 2017. - Manual of praying mantis morphology, nomenclature, and practices (Insecta, Mantodea). Zookeys 696: 1-100. https://doi.org/10.3897/zookeys.696.12542

BRUNNER VON WATTENWYL C. 1882. - Prodromus der europäischen Orthopteren. Verlag von Wilhelm Engelmann, Leipzig, 466 p. https://archive.org/details/bub_gb_szZDAAAAYAAJ_2

DJernÆs M., KlaSS K.-D., Picker M. D. \& DamgaARD J. 2012. Phylogeny of cockroaches (Insecta, Dictyoptera, Blattodea), with placement of aberrant taxa and exploration of out-group sampling. Systematic Entomology 37: 65-83. https://doi.org/10.1111/j.13653113.2011.00598.x

EHRMANN R. 1999. - Gottesanbeterinnen in Kopal und Bernstein (Insecta: Mantodea). Arthropoda 7: 2-10 + 3 figs.

Evangelista D. A., Djernes M. \& Kohli M. K. 2017. — Fossil calibrations for the cockroach phylogeny (Insecta, Dictyoptera, Blattodea), comments on the use of wings for their identification, and a redescription of the oldest Blaberidae. Palaeontologia Electronica (1FC) 20: 1-23. https://doi.org/10.26879/711

GratsheV V. G. \& ZHERIKHIN V. V. 1993. - New fossil mantids (Insect, Mantida). Paleontological Journal 27: 148-165.

GRIMALDi D. A. 2003. - A revision of Cretaceous mantises and their relationships, including new taxa (Insecta: Dictyoptera: Mantodea). American Museum Novitates 3412: 1-47. http://hdl. handle.net/2246/2838

GuO Y., BÉTHOux O., GU J.- J. \& REN D. 2013. — Wing venation homologies in Pennsylvanian 'cockroachoids' (Insecta) clarified thanks to a remarkable specimen from the Pennsylvanian of Ningxia (China). Journal of Systematic Palaeontology 11: 41-46. https://doi.org/10.1080/14772019.2011.637519

Hopkins H. 2014. - A revision of the genus Arenivaga (Rehn) (Blattodea, Corydiidae), with descriptions of new species and key to the males of the genus. Zookeys 384: 1-256. https://doi. org/10.3897/zookeys.384.6197

KedVES M. 1982. - The geology of the Menat basin, France. Palaeontographica Abteilung B Palaophytologie 182: 87-150.

Kedves M. \& Russell D. E. 1982. - Palynology of the Thanetian layers of Menat. The geology of the Menat Basin, France. Palaeontographica B 182: 87-150.

KLASS K.-D. \& MEIER R. 2006. - A phylogenetic analysis of Dictyoptera (Insecta) based on morphological characters. Entomologische Abhandlungen 63: 3-50.

LAMEERE A. 1922. - Sur la nervation alaire des insectes. Bulletin de la Classe des Sciences de l'Académie royale de Belgique 8: 138-149.

Lameere A. 1923. - On the wing-venation of insects. Psyche 30: 123-132. https://doi.org/10.1155/1923/16920

LATREILle P. A. 1829. - Le règne animal distribué d'après son organisation, pour servir de base à l'histoire naturelle des animaux et d'introduction à l'anatomie comparée. Nouvelle édition, revue et augmentée. Tome IV. Crustacés, arachnides et partie des insectes. Déterville, Crochard, Paris, i-xxvii + 1-584 p. https:// doi.org/10.5962/bhl.title. 49223

LEE S.-W. 2016. - Taxonomic diversity of cockroach assemblages (Blattaria, Insecta) of the Aptian Crato Formation (Cretaceous, NE Brazil). Geologica Carpathica 67: 433-450. https://doi. org/10.1515/geoca-2016-0027

Legendre F., Nel A., Svenson G. J., Robillard T., Pellens R. \& GrandColas P. 2015. - Phylogeny of Dictyoptera: dating the origin of cockroaches, praying mantises and termites with molecular data and controlled fossil evidence. PloS One 10: e0130127. https://doi.org/10.1371/journal.pone.0130127

LINNAEUS C. 1758. - Systema nature per regna tria nature, secundum classes, ordines, genera, species, cum characteribus, differentiis, synonymis, locis. Stockholm, Sweden, 824 p. https://doi. org/10.5962/bhl.title.542

MarTineZ-Delclos X. 1993. - Blátidos (Insecta, Blattodea) del Cretácico Inferiorb de España. Familias Mesoblattinidae, Blattulidae y Poliphagidae. Boletín Geológico y Minero 104: 516-538.

Nel A. 2008. - The oldest bee fly in the French Paleocene (Diptera: Bombyliidae). Comptes Rendus Palevol 7 (7): 401-405. https:// doi.org/10.1016/j.crpv.2008.08.001

Nel A. \& Roy R. 1996. - Revision of the fossil "mantid" and "ephemerid" species described by Piton from the Palaeocene of Menat (France) (Mantodea: Chaeteessidae, Mantidae; Ensifera: Tettigonioidea). European Journal of Entomology 93: 223-234.

Piton L. E. 1939. — Les orthoptères tertiaires d'Auvergne. Miscellanea Entomologica 37: 77-79+1 pl. 
Piton L. E. 1940. — Paléontologie du gisement éocène de Menat (Puy-de-Dôme) (flore et faune). Mémoires de la Société d'Histoire naturelle d'Auvergne 1: 1-303.

REHN J. W. H. 1951. - Classification of the Blattaria as indicated by their wings (Orthoptera). Memoirs of the American Entomological Society 14: 1-134.

Ross A. J. (in press). - The Blattodea (cockroaches), Mantodea (praying mantises) and Dermaptera (earwigs) of the insect Limestone (late Eocene), Isle of Wight, including the first record of Mantodea from the UK. Earth and Environmental Science Transactions of the Royal Society of Edinburgh.

SAussure H. DE \& ZeHnTNer L. 1894. - Insecta - Orthoptera Mantidae, in Saussure H. De, Zehntner L. \& Pictet A. (eds), Biologia Centrali-Americana. Taylor \& Francis, London, UK: 123-197. https://biodiversitylibrary.org/page/596195

Sharov A. G. 1962. - Redescription of Lithophotina floccosa Cock. (mantodea) with some notes on the manteod wing venation. Psyche 69: 102-106. https://doi.org/10.1155/1962/67682

STROIŃSKI A. \& SZWEDO J. 2012. — The oldest known Lophopidae planthopper (Hemiptera: Fulgoromorpha) from the European Palaeocene. Geobios 45: 413-420. https://doi.org/10.1016/j. geobios.2011.10.007

VRŠANSKÝ P. 2007. — Jumping cockroaches (Blattaria, Skokidae fam. n.) from the Late Jurassic of Karatau in Kazakhstan. Biologia 62: 588-592. https://doi.org/10.2478/s11756-007-0116-2

VRŠANSKÝ P. \& WANG B. 2017. - A new cockroach, with bipectinate antennae, (Blattaria: Olidae fam. nov.) further highlights the differences between the Burmite and other faunas. Biologia 72: 1327-1333. https://doi.org/10.1515/biolog-2017-0144

Wang Z., Shi Y., QIU Z., Che Y. \& Lo N. 2017. - Reconstructing the phylogeny of Blattodea: robust support for interfamilial relationships and major clades. Scientific Reports 7: 3903. https:// doi.org/10.1038/s41598-017-04243-1

Wappler T., Currano E. D., Wilf P., Rust J. \& Labandeira C. C. 2009. - No post-Cretaceous ecosystem depression in European forests? Rich insect-feeding damage on diverse middle Palaeocene plants, Menat, France. Proceedings of the Royal Society B 276: 4271-4277. https://doi.org/10.1098/rspb.2009.1255

WeSTWOOD J. O. 1835. - Art. 60. - Insectorum Arachnoidumque novorum decades duo. Zoological Journal, London 5: 440-443. https://biodiversitylibrary.org/page/27657803

ZherikHIN V. V. 2002. — Order Mantida Latreille, 1802. The mantises (= Mantodea Burmeister, 1838), in RASNITSYN A. P. \& Quicke D. L. J. (eds), History of Insects. Kluwer Academic Publishers Dordrecht: 273-276. https://doi.org/10.1007/0306-47577-4 